medRxiv preprint doi: https://doi.org/10.1101/2020.03.31.20046052; this version posted April 9, 2020. The copyright holder for this preprint (which was not certified by peer review) is the author/funder, who has granted medRxiv a license to display the preprint in perpetuity.

All rights reserved. No reuse allowed without permission.

\title{
Association of Dental Scaling with Lower Risk of Spontaneous Intracranial Haemorrhage: a Cohort Study in Taiwan
}

Jin-Shui Pan; Mei-Zhu Hong; Ben-Chang Shia; Linglong Ye; Lei Qin; Li-Juan Si

The authors have withdrawn this manuscript because several modifications are needed for study design and results. Therefore, the authors do not wish this work to be cited as reference for the project. If you have any questions, please contact the corresponding author. 